\title{
Latin America's information technologies: promises and realities
}

\author{
Estela Mastromatteo
}

Universidad Central de Venezuela, Caracas (Venezuela) Email: emastromatteo@gmail.com

\begin{abstract}
This contribution emphasizes that in order to achieve a real and sustainable human development in Latin America, and for this region to be part of the information society, it is extremely important to create conditions for a free access to information, education for everyone and in a permanent manner, and development in science and technology should be destined to serve society. Access to information and information technology are major promises in this era, but at the same time, become new forms of exclusion. In Latin America the two realities coexist. It is crucial in the solution to rethink the ethics of information and the values that underlie it, respect for human rights, the commitment of societies and our leaders. It also highlights the role of libraries as mediators in the production process, organization and retrieval of information access, in safeguarding the freedom of information and the right to free expression through technology, with ethics and values into a real development in Latin America.
\end{abstract}

Keywords: Information technologies, Information society, Information ethics, Information literacy, Latin America

Acknowledgement: The author is grateful to Professor Rafael Capurro and José María Díaz Nafría for his valuable review.

T oday's society is characterized by a growing and critical importance of information and knowledge to produce wealth. This constitutes the so-called information age, information society or knowledge society, represented by a society that uses, distributes, stores and creates new resources and information products through the use of information technologies and communication. The society starts from the individual, the citizen, as the final beneficiary of the user and recipient. This feature does not contradict the social dimension, on the contrary, it is strengthened when it interrupts positively in situations of severe inequality, discrimination or injustice (which suppress the rights in Latin America, the Caribbean and elsewhere). This situation supports the acting of a society with wisdom.

Humanity urgently requires to cause major qualitative progress for greater safety and welfare of sustainability. At the same time it requires the accomplishment of an educative level, quality of knowledge and the mastery of skills in the population. The multiplication of links, learning networks, the positive impact that may occur in culture and education, with the massive use of information technologies and communication, could contribute to this goal.

Learning to learn in an environment where constant change is necessary and urgent to build partnerships, contribute persistently in collective projects that transcend national boundaries it is a model of knowledge and skills management which contributes to the meeting and solidarity among cultures, the expression of multiple input and specific contents of goods and cultural values in favor of human development. Information technologies can be used for educational purposes and global promotion of culture. They offer the possibility of researching, organizing and managing information and knowledge, together with the use of different technologies and media such as cellular phone, fax, Internet, television, producing a huge cultural change to the extent that everyone, in theory, have access to knowledge, intangible cultural values and 
goods. This transforms the traditional spaces of knowledge and its dynamics, its contribution in a networked society and reaffirms the knowledge as the only means of returning to unity in life, seeking to maximize their wealth and property. As Toffler noted (1994):

"We live in a knowledge society, where
the basis of its production are data,
images, symbols, ideology, values,
culture, science and technology. The
most valuable asset is not the
infrastructure, machinery and equipment,
but the capacities of individuals to
acquire, create, distribute and implement
creative, responsible and critically
(wisely) knowledge in a context where
the fast pace of scientific and
technological innovation makes them
quickly obsolete."

Despite all expectations, still valid, we cannot ignore that we live in a society of inequality. In a society where those with greater access to information, education, and culture have better prospects and development opportunities, where many promises are converted into new forms of exclusion. While society has experienced significant changes in the economic, scientific, and technological aspects, these changes have not been able to determine a social change. This development has failed to find the possibility of social equality and solve the lack of basic needs in our populations. The XXI Century presents the largest of the contradictions. A happy world seems increasingly a utopia. The technology is, at the same time, the great promise and a factor of exclusion.

In Latin America, as in other so-called developing countries, the extreme opposites live together: great wealth and, at the same time, populations at the margin of society. Developments in software and hardware along with technological illiteracy and digital divide. Inventions that do not see the light in societies, lack of basic needs. As time passes, we are more in a third world. Frequently, the responsibility is attributed to the involvement of politicians or policies of the first world, but the fact is that a decay of our societies is present, one way or another, cause and a consequence of the lack of ethics and values. The information sector in Latin America is not exempt from this feature. The problem of inequalities in access to information goes beyond the technological issues and, as in other sectors, it focuses on social justice, to discover that it is not enough to make our societies capable of reading and writing, if they do not have the skills to understand and use information (functional literacy and informational) and use technology to improve their quality of life (technology or digital literacy).

This reality requires, in particular from the governments of developing countries, a considerable effort to understand the determinants of the phenomenon and to identify the mechanisms and variables that must be considered in a strategy towards building a knowledge society. It is necessary to generate innovative proposals, to change traditional patterns for development. It requires greater participation and integration of various actors and especially to bring order through strategies that must necessarily have the approval of society, in an issue that primarily affects many of the activities in developing nations, such as: education, state modernization, health, competitiveness, social policy, among others.

Information and communication technologies are not equalitarian, are more comfortably developed and used in the richest countries and within them, in the wealthier classes as a mechanism to replicate inequalities. However, there is a difference from traditional inequalities: technologies penetrate more strongly among young people. The digital divide is a good example of these technological inequalities. This is just new way of excluding people from information. This marginalization, of course, is not resolved by connecting computers in a network. It assumes, however, complying with the essential rights that promote an integrated development of the individual, enabling him to participate in this time of change, such as food, education, health and right to work. Considering the phenomenon only from a technological point of view is simplifying the problem. This important change is the main economic and social challenge for the countries of Latin America. These arguments 
suggest rethinking ways to address the core activities of development, as mentioned above, noting its complexity, which requires exploring the new forms of political leadership from Governments.

The production, dissemination and use of knowledge must become the main opportunity for growth in our countries. Otherwise, we will have no opportunity to participate in the digital development, and we will just be mere spectators. Development is caused by the knowledge that countries are able to generate, disseminate and manage. The differences continue to raise and deepen.

\section{Information ethics}

With regard to information ethics, we can make some reflections that may help in the Latin American context. Capurro ${ }^{1}$ (2008) points out that if ethics in general can be understood as a systematic reflection on the moral foundations of a "good life", as Aristotle conceived, the ethics of information is the reflection on the opportunities and problems caused by new technologies to make a "good life" at local and global levels as outlined in the Declaration of Principles and Plan of Action of the World Summit on the Information Society. The same author (2001) considers the ethics of information:

"... As a descriptive theory, which explores how the structures of power influence in the position assumed with regard to information and traditions in different cultures and eras. The ethics of information as a theory for emancipation, develop critics to moral attitudes and traditions in the field of information both individually and collectively."

From an interdisciplinary viewpoint constituted by information - education science and technology, in achieving the welfare of society, we can make three parallel necessary tracks, to emphasize the debate on information ethics, based on, among other approaches:

\footnotetext{
1 Rafael Capurro, Head of the International Center for Information Ethics (ICIE) is an obligatory reference in this topic.
}

- The World Summit on the Information Society (2003) proposed an information society for all and centered on people, which allows human beings the right to access to information and knowledge, based on recognition and respect for cultural identity, cultural and linguistic diversity, traditions and religions, and foster dialogue among cultures and civilizations.

- The Report to UNESCO of the International Commission on Education for the Twentyfirst Century (Delors, 2006) believes in lifelong learning as a democratic imperative of all four pillars related to learning to know, learning to do, learning to live together and learning to be. Facing the challenges of the future, education is an indispensable tool for humanity to progress toward the ideals of peace, freedom and social justice. The essential function of education is the continuous development of individuals and societies as a way to serve a more harmonious and genuine human development, to reduce poverty, exclusion, misunderstanding, oppression and war.

- The Rio Declaration on Ethics in Science and Technology (2003), which concentrated in the South American context, recognizes the need that in the creation of management policies of scientific and technological development, special attention is attributed to ethical implications, and that its principles guide efforts to ensure the welfare of people and autonomy of their nations. In defense of an international system that chooses to fight hunger and exclusion, even and especially the exclusion from knowledge in all its forms, as their priority, to promote quality education, right to health, education, housing and, at the same time, preventing abuse of power, condemn discrimination, intolerance and denounce the conditions that could lead to war and the breakdown of democratic structures.

These three approaches can be seen as ethical pillars necessary for the development of mankind, in which a set of universal values for the individual and collective development of our societies is included. Information ethics 
inherently sustains democratic values of pluralism, inclusiveness and tolerance.

\section{Promises and realities in Latin America}

Virtually all Latin American countries have defined strategies, plans, policies or agendas for a public policy on information and communication technologies, with mixed results. A regional strategy with defined goals and monitoring for the Regional Action Plan on the Information Society in Latin America and the Caribbean (Nicolai, 2007) developed in collaboration with ECLAC. The lack of results is the lack of measurement and monitoring of projects undertaken, along with initiatives that were abandoned or not started. The presence of national political agendas have different modalities, however, it has generally come from personal initiatives and leadership has been marked by lack of coordination, reduced and dispersed budgets, changes in emphasis and discontinuities over time, changes of government and responsibility for putting it forward.

We can mention aspects quantitatively encouraging. The figures, still poor in relation to developed countries, are continuously increasing (Tables 1 and 2) as well as government policies that could affect the matter. Among these, the supply of computers to students (Ceibal Plan, 65,739 units), Wi-Fi on buses (Montevideo); placing wireless Internet access in the local school and public squares (Uruguay), "info-centers", and socalled "virtual libraries" (Venezuela) with regard to the appropriation of information technology by societies.

Table 1: Internet Users in America Statistics (Nielsen-NetRatings, ITU, NICs, ISPs, 2005)

\begin{tabular}{cccccc}
\hline $\begin{array}{c}\text { Regions of } \\
\text { America }\end{array}$ & Population & Users & $\begin{array}{c}\text { \% Population } \\
\text { (penetration) }\end{array}$ & \% of Users & $\begin{array}{c}\text { Growth (2000- } \\
2007)(\%)\end{array}$ \\
\hline $\begin{array}{c}\text { Central } \\
\text { America }\end{array}$ & $142,671,074$ & $20,021,900$ & 14,0 & 6,7 & 522,3 \\
\hline Caribbean & $38,856,548$ & $4,298,409$ & 11,1 & 1,4 & 668,4 \\
\hline South America & $365,195,887$ & $48,633,288$ & 13,3 & 16,4 & 240,3 \\
\hline $\begin{array}{c}\text { Latin America } \\
\text { and Caribbean }\end{array}$ & $546,723,509$ & $72,953,597$ & 13,3 & 24,6 & 303,8 \\
\hline North America & $328,387,059$ & $224,103,811$ & 68,2 & 75,4 & 107,3 \\
\hline Americas & $875,110,568$ & $297,057,408$ & 33,9 & 100 & 135,5 \\
\hline
\end{tabular}

Table 2: Internet Users in Latin America Statistics (Nielsen-NetRatings, ITU, NICs, ISPs, 2005)

\begin{tabular}{cccccc}
\hline Region & $\begin{array}{c}\text { World } \\
\text { Population (\%) }\end{array}$ & Internet Users & $\begin{array}{c}\text { \% Penetration } \\
\text { in population }\end{array}$ & \% Users growth & World use (\%) \\
\hline Latin America & 8,4 & $135,082,809$ & 24,2 & 659,2 & 9,2 \\
\hline $\begin{array}{c}\text { Rest of the } \\
\text { world }\end{array}$ & 91,6 & $1,328,549,552$ & 21,7 & 287,1 & 90,8 \\
\hline World & 100,0 & $1,463,632,361$ & 21,9 & 305,5 & 100,0 \\
\hline
\end{tabular}

Among the countries with the highest population with Internet access in South America is Brazil, representing 34.7 (22.4\% of its population), $19.3 \%$ in Mexico (21.8\%), Argentina (39, 7\%), Peru (25.5\%) and Chile (43.2\%). Distinguished by their level of penetration: Chile (43.2\%), Argentina (39.7\%), Uruguay (31.8\%), Costa Rica (29.4\%) and Peru (25.5\%). Since 2000, among the countries of greatest increase are: Dominican
Republic (3718.2\%), Guatemala (1930.8\%), El Salvador (1650\%), Paraguay (1200\%) and Colombia $(1050 \%)^{2}$

It is also alarming, according to FernandezAballí (Agudo, 2000), the loss of privacy. Our personal data are in any number of

2 Internet World Stats, 2008. Available on: http://www.alcancelibre.org/article.php/200808210020044 46 
databases. This has given rise to an activity known as data mining, which allows private and governmental organizations, to conduct surveillance activities that affect our privacy. These activities are in most cases for commercial interests and not subject to any regulation. Moreover, in some countries there are lists, each one more detailed and sophisticated than the previous one, that have been used and are still used to deny or allow some rights, according to the political affiliation of a citizen; rights as the right to work, housing, health, retirement, etc.

Trying to consider all forms of tyrannies, without exception, let's start with right-wing military dictatorships in the decades of the fifties and seventies (after the Declaration of Human Rights, 1949). In these regimes, there were no freedoms or human rights, making it difficult to express in public and often with fear for the right to life. In Latin America, today, there are processes revolving around charismatic leaders who have persuaded the majority in the beginning, and once in power, manipulate and destroy the public governmental institutions. Enact and amend laws get artificial majorities to enable them to continue the conquest of absolute power. They use state resources excessively for populist purposes to ensure their popularity, regardless of the impact in medium and long term for the countries. Increasingly eager for power, they use the media to continue elevating their images.

Each of these regimes take control over the media, censoring and intimidating its directives, but continues to spread the idea that there is free press and freedom of speech. Without any regulation, six and more hours of government and political messages are mandatory. The notion of only one political party, with the creation of black lists, means officials outside the party or appearing on the lists are to lose their jobs or are unable to obtain employment. Party and State are confused. These regimes deal with an education that divides the population into paramilitary groups, identified by ideology or by wearing certain colors. Dissent and difference are persecuted.

Some recent laws and regulations are far outside the article 19 of the Declaration of
Human Rights, for example laws controlling the media, telecommunications, IT and postal services. Taken together, they seek political control of society, giving more power to each system. It is quite possible that some lines of the telecommunications project going in this direction, mimicking some governments that are recognized worldwide for its restrictions on Internet and telecommunications. ${ }^{3}$

\section{Role of Latin American libraries}

National and regional information policies must tackle the challenge of information society, to actively help our citizens and societies, especially the marginalized. They should promote community projects to help develop ideas and projects to build freedom. The latter can only be done through educational efforts that can benefit society as a whole. Information professionals need to learn through dialogue and critical analysis how to recognize and articulate ethical conflicts in the information field. (Capurro, 2001)

Under Article 19 of the Declaration of Human Rights (1949):

"Everyone has the right to freedom of opinion and expression; this right includes freedom to hold opinions without interference and to seek, receive and impart information and ideas through any media and regardless of frontiers."

The core mission of libraries is to satisfy the information needs of their users via services and products in a correspondence between the community and information resources. These are essential to ensure the information that individuals and societies require for their development. Within this process, information professionals have a key role in highlighting the ethical and professional commitment. Latin American libraries and information professionals, in line with the social need, highlighted by Ortega y Gasset (1935), should provide access to information regardless of social status or the existing socio-political regime. However, we found realities in Latin

\footnotetext{
${ }^{3}$ Marcelino Bisbal. Available on:

http://www.diariocritico.com/venezuela/2008/Septiemb re/noticias/97915/bisbal-internet-chavez-control.html
} 
America where the information professional and libraries have to make enormous efforts to ensure that this right becomes a reality, many times in the processes of production, organization, retrieval and access to information.

Capurro (1999) considers, regarding "the greatest concerns of librarians in the networked environment of today's world", the following ethical issues: privacy, intellectual property, censorship and the organization of knowledge. The issue of unequal access due to the different types of constraints (economic, cultural, political) is one of the major ethical issues along with the preservation of knowledge and its transmission to future generations.

In Cuba, since the beginning of the leftist dictatorship of Castro (1959), after the dictatorship of Fulgencio Batista, human rights were not contemplated, including the right to free access to information. Despite this, there is the independent libraries project, which aims to establish centers, according to its founders, promote reading not as the mere act of receiving knowledge, but to materialize and form an individual opinion freely, without censorship or obligation to a unique belief. It is noteworthy the civilian nature of the project, given its objective to create permanent institutions that promote the revitalization of an emerging civil society. Opening neutral spaces for culture devoted to reading, discussion, research and analysis of various materials and expand cultural and investigative horizons of everyone involved. Due to censorship, the population has been forced over time to satisfy their intellectual and professional curiosity in a clandestine manner, resorting to the black market in search of alternatives to the official publications. Only in this way, always illegal and punishable, they could get some books and documents into circulation, for the general population. ${ }^{4}$

In this regard, the IFLA / FLAIFE (1999) conducted a status report of the independent Cuban librarians and libraries, which condemns its repression. Since then, the situation has been intensified. Numerous

\footnotetext{
${ }^{4}$ Independent Libraries Project form Cuba. Available on: http://www.cubanet.org/bibliotecas/proyecto.htm
}

reports continue to be received on the repression of workers in libraries, including threats, assaults, police raids, beatings, arrests with subsequent 20 years imprisonment and the confiscation or burning of libraries collections.

\section{Conclusions}

Much has been talked on information and communication technologies globally and regionally. Some theorists see only positive aspects in the use of these tools. It is necessary, however to carry out a more thorough revision for developing countries, Latin America and other regions. These considerations are not anything new, authors such as Agudo (2000), Capurro (2005, 2008), Pimienta (2005), among others, have warned in this regard. With the first decade of this century at its end, there have been only intentions to solve the problem. Access to information, freedom of expression, and information technologies are a promise concerning its capabilities and new forms of exclusion. Can contribute to sustainable human development (economic, cultural, social, environmental) and to the income of countries in the information society and that these remain on the margins.

Capurro (2005) encourages us to reflect individually and collectively, in the middle of the obligations of the concrete political struggle, especially with regard to situations absolutely unsustainable that do not permit any kind of delay and thus indicate that we must think about information ethics in a spirit of openness and risk. Access to information in developing countries has to do with people who may have information regardless of their social, cultural or political background.

It is a good time, then, for taking sides in favor of the developing regions, to establish constructive criticism regarding information technology and bring all those aspects that are against information ethics, its values and of freedoms, and the human rights which have cost us so much. The discussion is necessary from the regions, so that, regardless of political affinities and sympathies, we can alert about arbitrary actions committed in this regard, actions that indicate, clearly, an involution. 


\section{References}

Agudo, A. (2000). Ética en la sociedad de la información: reflexiones desde América Latina y El Caribe. Caracas: [s.n.]. Asamblea General de Las Naciones Unidas (1949). Artículo 19 de la Declaración de derechos humanos. [Online] París: Naciones Unidas. <http://www.unhchr.ch/udhr/lang/spn.htm>

Capurro, R. (1999). Ethics aspects of digital libraries. [Online] <http://www.capurro.de>

Capurro, R. (2001). Ethics and information in the digital age. [Online] Annual Course and Conference: Libraries in the digital Age. Dubrovnik, Croatia, 23-27 may, 2001. <http://www.capurro.de/lida.htm>

Capurro, R. (2005). Ética de la información: un intento de ubicación. [Online] <http://www.capurro.de>

Capurro, R.; Gutiérrez, A. (2008). Ética intercultural de la información. [Online] <http://www.capurro.de>

Comisión Mundial de Ética del Conocimiento Científico y la Tecnología (COMEST) (2003). Declaración de Río de Janeiro sobre Ética en Ciencia y Tecnología. [Online] <portal.unesco.org/shs/en/files/6751/11222850171Declaracion_suscrita.pdf>

IFLA/FAIFE (1999). Las bibliotecas independientes de Cuba. [Online] <http://www.ifla.org/faife/faife/cubare_s.htm>

Nicolai, C. (2007). Políticas públicas para las tecnologías de la información y la comunicaciones en América Latina y EI Caribe. [Online] http://www.ahciet.net/portales/comun/pags/agenda/eventos/161/CEPAL\%20final.pdf

Ortega y Gasset, J. (1935). Misión del bibliotecario y otros ensayos afines. Madrid: Ediciones de la Revista de Occidente.

Pimienta, D. (1995). La pista de obstáculos desde las TIC hasta el desarrollo humano. [Online] $<$ http://funredes.org/espanol/publicaciones/index.php3/docid/469>

UNESCO; Delors, J. (1996). La educación encierra un tesoro: informe de la Comisión Internacional sobre la educación para el Siglo XXI. [Online] <www.unesco.org/education/pdf/DELORS_S.PDF>

Toffler, A.; Toffler, H. (1994). Las guerras del futuro. Barcelona: Olaza y Janés.

\section{About the Author}

Estela Mastromatteo

Magister Scientiarum in Communication and Information for Development. U.C.V. Committee of Postgraduate Studies (EHF-FACES-CENDES-FCJP) 2005, Degree on Library Science, 1998. Professor in the Librarianship and Archives School, Central University of Venezuela. University Libraries Consultant: Library of Pedro Grases, Metropolitan University, Center for Multiple Resources, National Open University; Miguel Acosta Saignes Library, Faculty of Humanities and Education, Central University of Venezuela. Member: Project BITRUM, (for an elucidation of the concept of interdisciplinary information) Leon, Spain, 2008; Novator Systems, Spain, 2008; Directory of Experts in Information Processing, Spain, 2007; International Center for Information Ehics (ICIE), Germany, 2007; International Registry for Authors (IRALIS), Spain, 2007; Educators for Sustainability, OEI, 2004. 